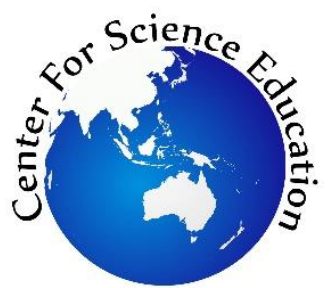

Tersedia online di EDUSAINS

Website: http://journal.uinjkt.ac.id/index.php/edusains

EDUSAINS,10(1), 2018, 1-7

Research Artikel

\begin{abstract}
KEMAMPUAN BERPIKIR KRITIS MAHASISWA PENDIDIKAN BIOLOGI MELALUI PENYELESAIAN MASALAH TOKSIKOLOGI LINGKUNGAN
\end{abstract}

\title{
CRITICAL THINKING ABILITY OF BIOLOGY EDUCATION STUDENTS THROUGH ENVIRONMENTAL TOXICOLOGY'S PROBLEM SOLVING
}

Laili Munawarah,Mochamad Arief Soendjoto, Bunda Halang

Program Magister Pendidikan Biologi Universitas Lambung Mangkurat, Jl. Brigjen Hasan Basri, Banjarmasin, Indonesia

laili.munawarah04@gmail.com

\begin{abstract}
In the era of globalization, science and technology that growing rapidly causing information flow becomes faster and limitless. This has a direct impact on many areas of life, including education. The process of education is required to prepare and produce quality human resources in order to process the information properly and correctly, by developing a culture of critical thinking. Critical thinking is a must-have capability of Bachelor Program's graduates in National Standards of Higher Education. Critical thinking is important to students because they can train themselves to be rational and choose the problem's best solution faced through the knowledge they have. But in fact the students are often still difficult to decide the right solution when faced with a problem around them. This problem must be addressed immediately, because it can lead to decreased quality of education and quality of human resources itself. One way to track and describe critical thinking ability is through the provision of problems related to Biology learning subjects. One of the subjects in Biology learning that deals with many issues around life is Environmental Toxicology. Environmental Toxicology issues can encourage students to find solutions to the dangers of contaminants and the work that can be done to minimize the impact of the contaminants.
\end{abstract}

Keywords:critical thinking ability; problem solving

Abstrak

Di era globalisasi, ilmu pengetahuan dan teknologi yang berkembang pesat menyebabkan aliran informasi menjadi lebih cepat dan tanpa batas. Hal ini berdampak langsung pada banyak bidang kehidupan, termasuk pendidikan. Proses pendidikan diperlukan untuk mempersiapkan dan menghasilkan sumber daya manusia yang berkualitas untuk memproses informasi dengan benar dan tepat, dengan mengembangkan budaya berpikir kritis. Berpikir kritis adalah kemampuan yang harus dimiliki lulusan Program Sarjana dalam Standar Nasional Pendidikan Tinggi. Berpikir kritis penting bagi siswa karena dapat melatih diri siswa untuk menjadi rasional dan memilih solusi terbaik dari masalah yang dihadapi melalui pengetahuan yang siswa miliki. Namun pada kenyataannya siswa seringkali masih kesulitan untuk memutuskan solusi yang tepat ketika dihadapkan dengan masalah di sekitar mereka. Masalah ini harus segera diatasi, karena dapat menyebabkan menurunnya kualitas pendidikan dan kualitas sumber daya manusia itu sendiri. Salah satu cara untuk membawa dan menggambarkan kemampuan berpikir kritis adalah melalui penyediaan masalah yang terkait dengan mata pelajaran pembelajaran Biologi. Salah satu materi dalam pembelajaran Biologi yang berhubungan dengan banyak masalah di sekitar kehidupan adalah Toksikologi Lingkungan. Masalah Toksikologi lingkungan dapat mendorong siswa untuk menemukan solusi terhadap bahaya kontaminan dan hal yang dapat dilakukan untuk meminimalkan dampak dari kontaminan.

Kata Kunci: kemampuan berpikir kritis; penyelesaian masalah

Permalink/DOI: http://dx.doi.org/10.15408/es.v10i1.6656 


\section{PENDAHULUAN}

Pada dasarnya, kemampuan berpikir diperlukan seseorang untuk membantu dirinya dalam menghadapi berbagai perubahan dan tantangan yang terjadi dalam perkembangan ilmu pengetahuan dan teknologi, khususnya kemampuan berpikir kritis. Bahkan pendidikan tinggi menetapkan standar bahwa mahasiswa yang menjadi lulusan Sarjana wajib memiliki kemampuan tersebut. Pada proses pembelajarannya, mahasiswa akan dihadapkan pada berbagai masalah, sehingga kemampuan berpikir kritis mereka diasah untuk menyelesaikan permasalahan tersebut dengan pengambilan keputusan tepat sebagai solusi. Namun kenyataannya dalam pembelajaran Biologi, mahasiswa seringkali masih kesulitan menemukan dan memutuskan solusi yang tepat ketika dihadapkan pada suatu masalah yang ada di sekitarnya, khususnya yang terkait dengan lingkungan.

Laporan-laporan hasil penelitian menggambarkan kurangnya pemikiran kritis mahasiswa. Ariyati (2010) menyebutkan bahwa rendahnya kualitas pendidikan disebabkan karena rendahnya kemampuan berpikir kritis peserta didik. Pada umumnya pembelajaran diarahkan hanya untuk menghapal dan menimbun informasi, sehingga mahasiswa pandai secara teoritis tetapi miskin secara aplikasi. Akibatnya kemampuan berpikir kritis menjadi kaku dan susah dikembangkan.

Permasalahan yang sama juga ditemukan pada penelitian Kurniasih (2010) yang melakukan penjenjangan kemampuan berpikir kritis mahasiswa FMIPA UNNES, bertujuan untuk mengetahui dan mendeskripsikan kemampuan berpikir kritis mahasiswa dari derajat tertinggi hingga derajat terendah. Namun hasil yang didapat adalah tingkat kemampuan berpikir kritis mahasiswa dalam menyelesaikan masalah hanya sampai tingkat kritis bahkan sebagian besar mahasiswa menunjukkan kemampuan berpikir kritis rendah.

Begitu pula yang terjadi di Universitas Tadulako Palu pada penelitian Maguna et al (2016) yang bertujuan mendeskripsikan kemampuan berpikir kritis mahasiswa Program Studi
Pendidikan Fisika tahun angkatan 2014. Hasil yang didapat yaitu mahasiswa belum mampu mencapai tingkat kritis dapat dilihat dari total 20 subjek penelitian, dimana 1 subjek penelitian berada pada kategori kurang kritis dan 19 subjek lainnya berada pada kategori sangat kurang kritis. Beberapa faktor yang menyebabkan rendahnya kemampuan tersebut diantaranya kurangnya kesiapan subjek penelitian dalam menjawab masalah yang diberikan serta masih kurangnya kemampuan berpikir kritis yang dimiliki mahasiswa.

Permasalahan kemampuan berpikir kritis mahasiswa ini tidak boleh dibiarkan berlarut-larut. Hal ini dapat menyebabkan penurunan kualitas pendidikan dan kualitas sumber daya manusia itu sendiri. Dalam rangka mengatasi permasalahan tersebut maka sebaiknya perlu lebih dulu mengetahui gambaran kemampuan berpikir kritis mahasiswa. Salah satu cara untuk melacak dan mendeskripsikan kemampuan berpikir kritis adalah melalui pemberian masalah yang terkait dengan konsep pembelajaran Biologi.

Salah satu konsep dalam pembelajaran Biologi yang banyak membahas permasalahan seputar kehidupan adalah Toksikologi Lingkungan. Pemberian masalah Toksikologi Lingkungan dapat mendorong mahasiswa untuk menemukan solusi berkenaan dengan bahaya bahan pencemar dan upaya yang dapat dilakukan untuk meminimalisir dampak dari bahan pencemar tersebut. Pengaplikasian pemberian masalah Toksikologi Lingkungan disajikan dalam pertanyaan-pertanyaan yang kemudian tercantum dalam tugas tertulis. Tiap-tiap pertanyaan pada tugas tertulis mengacu pada komponen berpikir kritis Paul-Elder dan penyelesaian masalah Polya.

\section{HASIL DAN PEMBAHASAN}

\section{Kemampuan Berpikir Kritis}

Kemampuan adalah karakteristik yang menonjol dari seorang individu yang berhubungan dengan kinerja efektif dalam suatu pekerjaan. Setiap mahasiswa yang telah mengalami proses belajar, kebiasaan-kebiasaannya akan tampak berubah. Kebiasaan-kebiasaan itulah yang nantinya akan disebut kemampuan. Menurut Burghardt dalam Syah (2014), kebiasaan itu timbul karena 
proses penyusutan kecenderungan respons dengan menggunakan stimulasi yang berulang-ulang.

Berpikir kritis termasuk dalam kemampuan berpikir tingkat tinggi.Hal ini dapat dilihat dari cara menginterprestasikan,menganalisis dan memanipulasi informasi. (Thompson, 2008). Selain itu, Weissinger (2004) berpendapat bahwa berpikir kritis merupakan kesadaran berpikir sendiri (self reflection), dan kemampuan serta kemauan (kemauan untuk bertanya) dalam mengklarifikasi dan meningkatkan pemahaman untuk membantu menarik kesimpulan dan mampu membuat keputusan terbaik.

Lebih lanjut Facione (2010) mengemukakan berpikir kritis merupakan kemampuan kognitif yang meliputi interprestasi (interpretation), analisis (analysis), evaluasi (evaluation), inferensi(inference), penjelasan (explanation), dan pengelolaan diri (self-regulation).

a. Interpretasi adalah kemampuan dalam memahami serta menjelaskan pengertian dari situasi, pengalaman, kejadian, data, keputusan, konvensi, kepercayaan, aturan, prosedur dan karakteristik.

b. Analisis dilihat dari cara mengidentifikasi hubungan dari berbagai pertanyaan, konsep, deskripsi, dan berbagai model yang digunakan dalam merefleksikan satu pemikiran, pandangan, kepercayaan, keputusan, alasan, informasi dan opini. Mengevaluasi ide dan pendapat orang lain serta mendeteksi argument dan menganalisa argument yang merupakan bagian dari analisis.

c. Evaluasi adalah kemampuan dalam menguji kebenaran pernyataan yang digunakan untuk menyampaikan pemikiran, persepsi, pandangan, keputusan, alasan, serta opini.

d. Inferensi dikaitkan dengan kemampuan mengidentifikasi dan memilih elemen yang digunakan dalam menyusun kesimpulan beralasan, untuk menduga dan menegakkan diagnosis, serta memperitmbangkan informasi apa saja yang dibutuhkan dan memutuskan konsekuensi yang diambil dari data, informasi, pertanyaan, kejadian, prinsip, opini, dan konsep.

e. Penjelasan merupakan kemampuan untuk menyatakan hasil pemikiran dari penjelasan yang berdasarkan bukti, konsep metodologi, kriteriologi dan konteks. Termasuk dalam kemampuan menyampaikan hasil, menjelaskan prosedur, dan mempresentasikan argumen.

f. Kemampuan diri merupakan kemampuan seseorang untuk mengatur diri sendiri untuk berpikir. Kemampuan ini akan selalu memeriksa ulang hasil berpikirnya yang kemudian diperbaiki sehingga menghasilkan keputusan yang lebih baik.

\section{Teori Berpikir Kritis Paul-Elder}

Ada berbagai macam teori berpikir kritis yang dikemukakan para ahli, salah satunya oleh Richard Paul dan Linda Elder. Berpikir kritis merupakan cara bagi seseorang untuk meningkatkan kualitas dan hasil pemikiran menggunakan teknik sistemasi cara berpikir dan menghasilkan daya pikir intelektual dalam ide-ide yang digagas (Paul dan Elder, 2005). Seseorang yang berpikir secara kritis akan dapat menjawab permasalahan-permasalahan dengan baik. Dia akan berpikir secara jelas dan tepat. Seorang yang berpikir kritis dapat menggunakan ide yang abstrak untuk bisa membuat model penyelesaian masalah secara efektif.

Menurut Paul (2007), ada 3 macam komponen berpikir kritis, yaitu: (1) elemen bernalar, (2) standar intelektual bernalar dan (3) karakter intelektual bernalar, Paul dan Elder (1996) lebih rinci menjelaskan elemen bernalar terdiri atas 8 bagian, yaitu: (1) Tujuan (purpose), (2) Pertanyaan (questions), (3) Asumsi (assumptions), (4) Sudut Pandang (points of view), (5) Informasi (information), (6) Konsep dan ide (concepts), (7) Penyimpulan (inferences), (8) Implikasi (implications). Adapun standar intelektual bernalar (Paul dan Elder, 2008) terdiri atas 7 komponen, yaitu: (1) Kejelasan (clarity), (2) Ketepatan (accuracy), (3) Ketelitian (precision), (4) Relevansi (relevance), (5) Kedalaman (depth), (6) Keluasan (breadth), dan (7) Logis (logic). Selanjutnya untuk karakter intelektual bernalar (Paul dan Elder, 2014) terbagi atas 7 karakter, yaitu: (1) Kerendahan Hati 
Intelektual (intellectual humility), (2) Keberanian Intelektual (intellectual courage), (3) Empati Intelektual (intellectual empathy), (4) Integritas Intelektual (intellectual integrity), (5) Ketekunan Intelektual (intellectual preseverance), dan (7) Berpikir Terbuka (fair-mindedness).Di bawah ini skema hubungan antara ketiga komponen berpikir kritis.

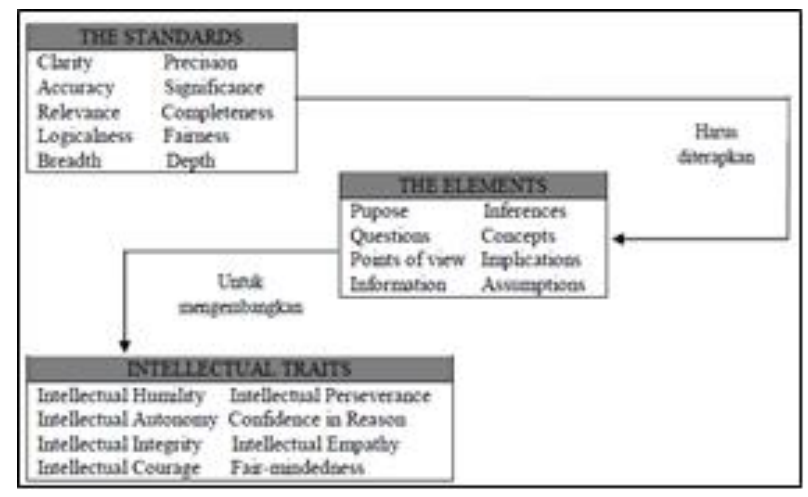

Gambar 1. Skema Hubungan Standar Intelektual Bernalar, Elemen Bernalar Dan Karakter Intelektual Bernalar (Paul dan Elder, 2008)

Berdasarkan ketiga komponen berpikir kritis menurut Paul dan Elder, diketahui bahwa mengembangkan berpikir kritis itu tidaklah mudah, karena berpikir kritis seseorang tidak dapat langsung diketahui hasilnya dan harus melalui berbagai proses yang dapat dilihat hubungannya dari ketiga komponen yaitu standar intelektual bernalar, elemen bernalar dan karakter intelektual bernalar. Namun dikarenakan untuk meneliti dan mengetahui komponen karakter intelektual memerlukan waktu yang lama, biasanya penelitian yang dilakukan mengacu pada komponen elemen bernalar dan standar intelektual bernalar saja seperti penelitian yang dilakukan Kurniasih (2010).

\section{Penyelesaian Masalah Polya}

Penyelesaian masalah atau problem solving adalah proses menerapkan pengetahuan yang telah diperoleh sebelumnya ke dalam situasi baru yang belum dikenal. Mahmudi (2008) mengemukakan bahwa penyelesaian masalah mempunyai berbagai peran yaitu sebagai kemampuan, pendekatan dan konteks. Dikarenakan pemikiran kritis tidak tumbuh dan berkembang di ruang hampa, sehingga ia memerlukan sarana atau yang disebut juga sebagai konteks dan penyelesaian masalah dapat dijadikan sebagai sarana tersebut.
Penyelesaian masalah George Polya terdiri atas 4 tahapan yang lebih dikenal dengan See (memahami masalah), Plan (menyusun rencana), Do (melaksanakan rencana) dan Check (menguji jawaban). Hamiyah dan Jauhar (2014) lebih rinci menjelaskan sintak atau tahapan-tahapan Polya untuk menyelesaikan masalah yaitu (1) Memahami masalah dengan mengemukakan dan memperjelas masalah, (2) Menyusun rencana penyelesaian masalah berdasarkan pengalaman yang dimiliki sebelumnya (3) Melaksanakan rencana penyelesaian masalah sesuai dengan rencana yang dianggap paling tepat, dan (4) Mengecek kembali hasil penyelesaian masalah agar kesalahan terkoreksi kembali dan sampai pada jawaban yang sesuai dengan masalah.

\section{Identifikasi Berpikir Kritis melalui Penyelesaian Masalah Toksikologi Lingkungan}

Kemampuan berpikir kritis berbeda-beda pada setiap individu, tergantung latihan yang sering dilakukan untuk mengembangkan kemampuan berpikir kritisnya. Muyassaroh (2013) menjelaskan bahwa melalui tes dengan indikator bertanya dan menjawab pertanyaan yang membutuhkan penjelasan, melakukan deduksi, melakukan induksi, membuat nilai keputusan, dan memutuskan suatu tindakan dapat meningkatkan kemampuan berpikir kritis seseorang. Tes tersebut kemudian dapat disajikan melalui pemberian masalah dalam bentuk soal yang bervariasi. Hal ini sesuai dengan penjelasan Maguna (2016) bahwa kemampuan berpikir kritis seseorang itu dapat dilacak dengan baik melalui pemberian masalah. Gokhale (1995) juga menyebutkan bahwa kemampuan berpikir kritis seseorang dapat diketahui dengan pemberian soal yang melibatkan analisis, sintesis, dan evaluasi dari suatu konsep.

Toksikologi Lingkungan merupakan salah salah satu konsep dalam pembelajaran Biologi yang erat pembahasannya dengan masalah-masalah lingkungan yang terjadi saat ini. Pokok bahasan seperti Toksikan Polutan Udara dan Air sangat cocok menjadi tema masalah yang diangkat dalam tugas tertulis. Tema ini dapat diambil dari berbagai sumber media baik artikel maupun berita. Pemberian masalah yang disajikan dalam tugas tertulismemuat pertanyaan-pertanyaan terkait 
wacana yang berisi isu-isu toksikologi lingkungan. Isu-isu tentang masalah tersebut sebaiknya yang terjadi dekat dengan tempat tinggal. Bagi mahasiswa yang berdomisili di Kalimantan Selatan dapat mengambil masalah misalnya tentang pencemaran air oleh limbah tambang batubara dan pencemaran udara oleh kabut asap akibat pembakaran lahan.

Pertanyaan-pertanyaan tugas tertulis memuat elemen-elemen bernalar Paul dan Elder (2008) dan disusun berdasarkan sintak penyelesaian masalah Polya. Elemen-elemen bernalar Paul dan Elder diterapkan dalam tugas tertulis sebagai indikator kemampuan berpikir kritis.

a. Tujuan (purpose) yaitu seberapa bisa seseorang mendefinisikan tujuan dengan jelas untuk memahami beberapa hal

b. Pertanyaan (questions) yaitu usaha untuk menjawab pertanyaan yang menjadi masalah, dapat dilakukan dengan cara menggambarkan sesuatu, menetapkan pertanyaan dan menyelesaikan masalah.

c. Asumsi (assumptions) yaitu mencoba mengidentifikasi asumsi dengan jelas dan menentukan asumsi dapat dipertanggungjawabkan atau tidak serta bagaimana asumsi tersebut membentuk sudut pandang

d. Sudut Pandang (points of view) yaitu dibuat dengan memperhatikan beragam sudut pandang sehingga dapat memberikan beragam alternatif penyelesaian.

e. Informasi (information) yaitu. mencoba mengidentifikasi informasi baik data maupun fakta, meyakinkan bahwa informasi yang digunakan jelas dan relevan dengan pertanyaan yang menjadi pokok masalah

f. Konsep dan ide (concepts) yaitu dinyatakan dalam bentuk yang berdasarkan konsep dan ide seperti definisi, teori, prinsip, aturan dan model.

g. Penyimpulan (inferences) yaitu penarikan kesimpulan dan memberi pengertian dari kesimpulan. h. Implikasi (implications), yaitu menemukan implikasi dan konsekuensi baik negatif dan positif dari penalaran yang dilakukan.

Hasil jawaban mahasiswa kemudian dinilai berdasarkan standar intelektual bernalar. Deskripsi tiap komponen standar intelektual bernalar.

a. Kejelasan (clarity) yaitu elemen bernalar yang ditemukan pada wacana apakah sudah jelas, mudah dimengerti dan tidak menimbulkan makna ganda.

b. Ketepatan (accuracy) yaitu elemen bernalar yang ditemukan pada wacana apakah sudah mengandung kebenaran, tidak menyimpang dari pertanyaan dan isi wacana.

c. Ketelitian (precision), yaitu elemen bernalar yang ditemukan pada wacana apakah sudah terperinci, detail dan saksama.

d. Relevansi (relevance) yaitu elemen bernalar yang ditemukan pada wacana apakah sudah berkaitan dengan masalah yang terdapat pada isi wacana.

e. Kedalaman (depth) yaitu elemen bernalar yang ditemukan pada wacana apakah sudah ditelaah lebih dalam dan mengandung kompleksitas yang terorganisir.

f. Keluasan (breadth) yaitu elemen bernalar yang ditemukan pada wacana apakah sudah beragam dan disediakan dengan berbagai alternatif.

g. Logis (logic) yaitu elemen bernalar yang ditemukan pada wacana apakah sudah masuk akal dan sesuai dengan logika.

Penilaian hasil jawaban dilakukan dengan penskoran. Tiap-tiap pertanyaan mewakili elemen bernalar tertentu. Jika mahasiswa dapat menjawab benar 1 pertanyaan, dengan memenuhi semua komponen standar intelektual bernalar, maka ia akan memperoleh bobot skor maksimal. Dikarenakan jumlah pertanyaan sama dengan jumlah elemen bernalar yaitu 8 maka bobot skor maksimalnya adalah 12,5. Skor total keseluruhan adalah 100 . 


\section{PENUTUP}

Pada pembelajaran Biologi, kemampuan berpikir kritis diperlukan mahasiswa untuk membantu dirinya dalam menghadapi berbagai permasalahan yang berkaitan dengan ilmu Biologi yang mana dilalui dengan pengambilan keputusan tepat sebagai solusi. Namun, seringkali mahasiswa masih banyak yang kesulitan menemukan dan memutuskan solusi yang tepat tersebut.

Permasalahan kemampuan berpikir kritis ini tidak boleh dibiarkan berlarut-larut. Hal ini dapat menyebabkan penurunan kualitas pendidikan dan kualitas sumber daya manusia itu sendiri. Untuk itu, sebaiknya perlu lebih dulu mengetahui gambaran kemampuan berpikir kritis mahasiswa. Salah satu cara untuk melacak dan mendeskripsikan kemampuan berpikir kritis adalah melalui pemberian masalah. Konsep Toksikologi Lingkungan cocok diangkat sebagai tema masalah karena erat kaitannya dengan masalah lingkungan yang terjadi saat ini. Pengaplikasian pemberian masalah Toksikologi Lingkungan disajikan dalam pertanyaan-pertanyaan tugas tertulis. Tiap-tiap pertanyaan pada tugas tertulis mengacu pada komponen berpikir kritis elemen bernalar dan standar intelektual bernalar Paul-Elder dan tersusun sesuai sintak penyelesaian masalah Polya.

\section{DAFTAR PUSTAKA}

Ariyati, E. 2010. PembelajaranBerbasis Praktikum untuk Meningkatkan Kemampuan Berpikir Kritis Mahasiswa. Jurnal Matematika dan IPA, 1(2), 1-11.

Facione, P.A. 2010. Critical Thinking: What It Is and Why It Counts. Retrieved from http://www.insightassessment.com/pdf_files/ what\%26why2006.pdf.

Gokhale. A.A.1995. Collaborative Learning Enhances Critical Thinking. Journal of Technology Education. 7 (1). 22-30.

Hamiyah, N.,Jauhar, M. 2014.Strategi Belajar Mengajar di Kelas. Jakarta: Prestasi Pustaka.

Kurniasih, A.W. 2010. Penjenjangan Kemampuan Berpikir Kritis Mahasiswa Prodi Pendidikan Matematika FMIPA UNNES dalam
Menyelesaikan Masalah Matematika. Prosiding Seminar Nasional Matematika dan Pendidikan Matematika, Prodi Pendidikan Matematika FMIPA UNY, Yogyakarta.

Maguna, A., Darsikin, Pasaribu, M. 2016. Kemampuan Berpikir Kritis Mahasiswa Calon Guru pada Materi Kelistrikan (Studi Deskriptif pada Mahasiswa Program Studi Pendidikan Fisika Universitas Tadulako Tahun Angkatan 2014). Jurnal Pendidikan Fisika Tadulako, 4(3), 46-51.

Mahmudi, A. 2008. Pemecahan Masalah dan Berpikir Kreatif. Palembang: Universitas Sriwijaya.

Muyassaroh, L. 2013. Efektivitas Pembelajaran Berbasis Masalah dengan Open-Ended pada Materi Listrik Dinamis terhadap Kemampuan Berpikir Kritis Siswa. Unpublished script. UIN Sunan Kalijaga.

Paul, R., Elder, L. 1996. Using Intellectual Standard to Assess Student Reasoning. Retrieved from http://www.criticalthinking.org/pages/usingintellectual-standards-to-assess-studentreasoning/602.

Paul, R., Elder, L. 2005. The Miniature Guide to Critical Thinking Concepts and Tools. Retrieved from http://www.criticalthinking.org/pages/definin g-critical-thinking/766.

Paul, R. 2007. Critical Thinking in Every Domain of Knowledge and Belief. Retrieved from http://www.criticalthinking.org/pages/critical -thinking-in-every-domain-of-knowledgeand-belief/698.

Paul, R., Elder, L. 2008. The Thinker's Guide to Intellectual Standard. Retrieved from http://www.criticalthinking.org/pages/univer sal-intellectual-standards/527.

Paul, R., Elder, L. 2014. Valuable IntellectualTraits. Retrieved from http://www.criticalthinking.org/pages/valuab le-intellectual-traits/528. 
Syah, M. 2014. Psikologi Pendidikan dengan Pendekatan Baru. Bandung: Remaja Rosdakarya Offset.

Thompson, T. 2008. Mathematics Teachers' Interpretation of Higher-Order Thinking in Bloom's Taxonomy. IEJME, 3(2), 96-109.
Weissinger, P.A. 2004. Critical Thinking, Metacognition, and Problem Based Learning. In Tan Oon Seng (ed). Enhancing Thinking through Problem Based Learning Approaches. Singapore: Thomson. 